one. The existing treatises on British reptiles are either antiquated or compiled by writers insufficiently versed in the subject. It is only regrettable that Dr. Leighton, whilst engaged in the preparation of this little work, which contains much interesting matter, should not have made himself more thoroughly acquainted with what has been published on the subject, in England at least, as we notice the omission of important information which might have been obtained through reference to the volumes of the Zoologist and to the British Museum Catalogue of Snakes, of which he appears to be ignorant. The descriptions of the three species which make up the British ophidian fauna are inadequate, and this is all the more to be regretted since many points of structure and coloration which are subject to variation would have afforded an important topic in which to arouse the interest of the field-naturalist.

The reproduction of many of the photographs which are liberally scattered through the work leaves much to be desired, and the figures of the head-shields of the ring-snake or grass-snake and the smooth snake, as well as of the scales round the eye in the adder, are very inaccurate. True, the work is only intended for the nonscientific, who may perhaps not feel inclined to be too exacting on these points, if we bear in mind how few have the necessary training of the eye, in matters reptilian, to detect inaccuracies which would hardly be tolerated if they applied to birds or insects.

The book is made up to a great extent of letters from correspondents and of newspaper cuttings referring to distribution, size and habits, the adder's "swallowing of the young for protection" being, of course, the heading of an important chapter. All this is very useful and interesting information, and is well commented upon by the author.

It is not without surprise that we notice an attempt to restore the "small red viper," Coluber chersea of Linnæus, to the rank of a distinct species, under the new name of Vipera rubra, which is regarded by the author as "quite as distinct from the ordinary adder as a swallow is from a martin." On the other hand, Sowerby's Coluber dunfrisiensis, which still appears in the synonymy of the smooth snake (Coronella austriaca), is a distinct species, which inhabits North America and was erroneously ascribed to Scotland. In describing the common grass-snake it should have been stated that the yellow or orange collar is sometimes absent in adult specimens. It is held by most observers who have kept this snake that its food consists of nothing higher in the vertebrate scale than batrachians; but Dr. Leighton informs us that one of its most favourite meals consists of mice, and that it also feeds on water-voles and birds. The only instance known to the writer of this notice of a grass-snake containing a mouse is that of a sciagraph exhibited before a meeting of the Zoological Society of London a few years ago; but an inquiry elicited the fact that the mouse had been forcibly introduced. It is desirable that Dr. Leighton should adduce some more precise data in support of his statement.

In spite of the defects to which we have drawn attention, this little book will be of use and interest to fieldnaturalists, and will no doubt result in greater attention being bestowed on a somewhat neglected section of vertebrates.

G. A. B.

The Feeding of Animals. By W. H. Jordan. Pp. xvii +450 . (New York: The Macmillan Company; London: Macmillan and Co., Ltd., rgor). Price 5s. net.

THE author takes a wide range. Beginning with a popular account of the chemical constituents of plants and animals, the processes of digestion and nutrition, and the functions of food in the body, he then proceeds to a description of cattle foods, and to the actual results NO. I669, VOL. 64] obtained by the use of food as ascertained by scientific investigations and farm practice. The book is written in a somewhat diffuse and popular style, and the different parts are of unequal merit, but it is of undoubted value. The author is not pledged to any special theories, but readily accepts every well-proved fact. $\mathrm{He}$ is well acquainted with the most recent German and American investigations, and has brought together a large number of very important new results, for which teachers will heartily thank him. Had the author written with greater accuracy for science students, instead of writing for the half-educated general reader, he would probably have produced a better book on the feeding of animals than has hitherto appeared in the English language.

The book is thoroughly American, and the author illustrates every part of the subject as far as possible by the investigations and practice of his own country. He is naturally bound by American conventions, and to one of these we must strongly demur. The whole of the nitrogenous substances present in any vegetable food are collectively spoken of as "protein," although, in fact, a large part of them may be amides, and in some cases nitrates. This is distinctly worse than the German plan of calling the whole group "Rohprotein," as in this case some qualification is expressed. The American nomenclature results in a confusion of language which must be abhorent to every physiological chemist. Thus our author says (p. 179): "A much larger part of the protein of roots consists of amides than is the case with the grains, the protein of the latter being correspondingly richer in albuminoids." It is surely far better to give the collective nitrogenous matters the general title of "nitrogenous substance" instead of applying to them the name of a particular body, which in some cases forms only a small part of the group. The error is all the more important as the amount of true proteids present in a food has generally a great influence upon its nutritive value.

The chapter by Mr. W. P. Wheeler on the feeding of poultry is of considerable importance, as he brings before us the results of many recent American investigations.

\section{R. W.}

\section{First Stage Building Construction. By Brysson Cunningham, B.E., Assoc. M.Inst.C.E. Pp. viii +240.} (London: W. B. Clive.) Price $2 s$.

THIS small volume on elementary building construction forms one of the "organised science series." It is intended for students preparing for the examinations in elementary building construction under the Board of Education. There are already several books published which cover the same course, but none, we believe, which profess to do so at the modest price of $2 s$., as does the volume before us. Mr. Cunningham's book does not call for much comment. The information given is of the kind required, and is well and tersely put in a practical way, but the diagrams, which are so important in a book of this kind, are in many cases very carelessly drawn, and do no credit to the book. If these are improved in a future edition, it will render the book more valuable.

Théorie Nouvelle de la Dispersion. Par M. G. Quesneville. Pp. 72. (Paris: A. Hermann, I90I.)

WE opened this book in the hope of finding an intelligent criticism of modern theories of dispersion and an attempt to substitute something better; but the author appears to be very imperfectly acquainted with them ; for instance, there is no reference to Sellmeier, or to Lord Kelvin's Baltimore lectures. His criticisms are mainly directed to the writings of Cauchy. The "new theory "does not appear to include any new suggestion as to physical mechanism, or anything to repay the labour of wading through sixty pages of algebraic developments. 